\title{
Analisis Kebijakan Musyawarah Perencanaan Pembangunan (MUSRENBANG) Kabupaten Sumenep
}

\author{
Moh. Farid1), Totok Sasongko 2), Annisa Purwatiningsih ${ }^{3) .}$ \\ Program Studi Ilmu Administrasi Publik \\ Sekolah Pasca Sarjana \\ Universitas Tribhuwana Tunggadewi \\ e_mail: faridsanti99@gmail.com
}

Received: 20 September 2020; Revised: 03 Oktober 2020; Accepted : 19 November 2020; Published : December 2020; Available online : December 2020.

\begin{abstract}
The Process of Development Planning Discussion (MUSRENBANG) is successful if the result of Muernbang can be implemented become maximal. So in the Implementation of both from the village level, sub district level, regencg level even merely fulfill the obligations for the realization of the program, but can be implemented well from the result of MUSRENBANG. The type of this riset are use descriptive quantitative method, secandary data and primary data, in this case we use accumulate data thecniqve by specific interview observation and documentation. While, to choose the informan we use purposive sampling thecniqve and analysis data thecniqve by reduction of data, presenting data and then we dray the conclusion. From the result of this riset, the government of Sumenep regency that belongs in the unit of work on that region have been done the MUSRENBANG of both from the village level, become maximal. Even merely fulfill doing the process of MUSRENBANG wel done. Althaugh there are some unrealization program, but it can understandabhg, because the limitations of the budget provided by the government. But the appreciation of Jawa Timur governoor about Sumenep regency is being process and MUSRENBANG Implementation of Sumenep regency is trully kept and the government of Sumenep regency responsibly.
\end{abstract}

\section{Keywords: Development Planning Discussion; Village Level, Sumenep}

\section{Pendahuluan}

$$
\text { Musyawarah }
$$

Perencanaan

Pembangunan yang sering kita kenal dengan sebutan Musrenbang, adalah sarana Pemerintah disemua tingkatan, untuk menghimpun aspirasi pembangunan disemua bidang kehidupan masyarakat. Disisi lain Musyawarah Perencanaan Pembangunan (Musrenbang) merupakan cerminan dari praktik partisipasi warga dan sekaligus arena akuntabilitas Pemerintahan, baik dari jajaran pimpinan Daerah, kalangan masyarakat dari berbagai komponen, 
dan kalangan usaha/bisnis, dapat bertemu dan berdialog mengenai program Daerahnya dengan tujuan Musrenbang sebagai penyempurna dari Rancangan Awal Rencana Kerja Pemerintah Daerah RKPD

Musyawarah

Perencanaan

Pembangunan (Musrenbang) baik dari tingkat Desa/Kelurahan sampai Tingkat Kabupaten/Kota itu semua merupakan forum antar pelaku dalam rangka penyusunan Rencana Pembangunan Nasional dan Rencana Pembangunan Daerah. Jadi implementasi dari Musrenbang Daerah berpedoman kepada Surat Edaran Bersama antara Menteri Perencanaan Pembangunan Nasional/Ketua BAPPENAS dan Menteri Dalam Negeri Nomor : 1354/M.PPN/13/2014 Tentang Pedoman Pelaksanaan Forum Musrenbang dan Perencanaan Partisipatif Daerah. Dalam pedoman tersebut dijelaskan bahwa Musyawarah Perencanaan Pembangunan (Musrenbang) dimulai dari Musrenbang tingkat Desa/Kelurahan, Musrenbang tingkat Kecamatan, Musrenbang tingkat Kabupaten/Kota dan Musrenbang tingkat Provinsi.

$$
\text { Pada tingkat masyarakat }
$$
(desa/kelurahan), Musrenbang sebagai salah satu bentuk pencapaian kesepakatan tentang prioritas program Satuan Kerja Perangkat Daerah (SKPD). Dan juga untuk menghimpun aspirasi pembangunan disemua bidang kehidupan masyarakat yang mana advokasi masarakat akan di bawa pada tingkatan yang lebih tinggi, karena dikira penting bagi masyarakat untuk mengembangkan kemajuan Daerahnya dalam prespektif pembangunan tersebut. Kenapa demikian? Suatu kemajuan Daerah itu yang pertama bergantung pada perencenaan pembangunan yang tertata dengan baik. Tentunya dengan Musyawarah Perencanaan Pembangunan (Musrenbang) tingkat Desa/Kelurahan yang akan menjadi wadah untuk mengaktualisasikan suara/aspirasi masyarakat pada Pemerintahan yang lebih tinggi.

Musrenbang tingkat Kecamatan adalah musyawarah tahunan di tingkat kecamatan, dalam rangka untuk mendapatkan masukan, konfirmasi, klarifikasi, dan berbagai prioritas yang berdasarkan hasil Musrenbang tingkat Desa/Kelurahan. Dengan beberapa tujuan : yang pertama mendorong peran dan partisipasi masyarakat dalam merumuskan dan pengambilan keputusan bersama-sama Pemerintah 
dalam penyusunan perencanaan pembangunan tahunan di tingkat kecamatan, yang kedua Musrenbang tingkat Kecamatan bertujuan untuk membahas prioritas permasalahan hasil Musrenbang tingkat Desa/Kelurahan diwilayah kecamatan yang bersangkutan, yang ketiga melakukan klasifikasi atas prioritas permasalahan pembangunan kecamatan sesuai dengan fungsi-fungsi Satuan Kerja Perangkat Daerah (SKPD), dan yang terakhir adalah menetapkan daftar urutan prioritas permasalahan yang akan diusulkan pada forum SKPD.

Pada tingkat Kabupaten/Kota, Musrenbang adalah sebagai musyawarah pemangku kepentingan (stakeholder) untuk memantapkan rancangan RKPD tingkat Kabupaten/Kota berdasarkan rancangan SKPD hasil Musrenbang SKPD dalam rangka memantapkan keserasian antara Rancangan Renja SKPD dengan rancangan awal RKPD yang telah disusun oleh BAPPEDA (Nandang\& Saeful.2008:18). Karena prioritas program/kegiatan yang telah dipilih menurut sumber pendanaan dari APBD, APBD Provinsi dan APBN, selanjutnya menjadi rujukan pada proses penyusunan anggaran tahunan Daerah.

Terlepas dari berbagai asumsi diatas Musyawarah Perencanaan
Pembangunan (Musrenbang) tingkat Kabupaten itu juga merupakan kewajiban Daerah sebagai implementasi Undang-Undang Nomor 25 tahun 2004 tentang Sistem Perencanaan Pembangunan Nasional, jadi sesuai dengan dasar hukum tersebut, Pemerintah Daerah wajib untuk menyusun Rencana Kerja Pemerintah Daerah (RKPD). Proses pembahasan Rancangan RKPD harus dilaksanakan melalui Musrenbang yang partisipatif, demokratis dan adaptif. Bukan hanya sekedar wajib melaksanakan proses pelaksanaan Musrenbang saja, akan tetapi mengimplementasikan dari hasil Musrenbang Kabupaten Sumenep tentunya itu juga merupakan kewajiban bagi Pemerintah Sumenep.

Atas dasar berbagai permasalahan diatas, sehingga peneliti mengambil judul tentang "Implementasi Kebijakan Musyawarah Perencanaan Pembangunan (MUSRENBANG) di Kabupaten Sumenep", berdasarkan latar belakang maka rumusan masalah sebagai berikut : 1. Bagaimana implementasi kebijakan Musrenbang di tingkat Kabupaten/Kota Sumenep? Dan 2. Bagaimana strategi Pemerintah dalam mengimplementasikan hasil Musrenbang di tingkat Kabupaten/Kota Sumenep? 
Tujuan dari penelitian ini untuk mengetahui dan menganalisa sejauhmana implementasi kebijakan Musrenbang di tingkat Kabupaten/Kota Sumenep sampai saat ini, dan untuk mengetahui strategi Pemerintah dalam mengimplementasikan kebijakan hasil Musrenbang di tingkat Kabupaten/Kota Sumenep.

Secara etimologis, implementasi merupakan suatu aktivitas yang bertalian dengan penyelesaian suatu pekerjaan dengan penggunaan sarana (alat) untuk memperoleh hasil. Terminologi implementasi kebijakan publik dapat diartikan sebagai aktivitas penyelesaian atau pelaksaan suatu kebijakan publik yang telah ditetapkan/disetujui dengan penggunaan sarana (alat) untuk mencapai tujuan kebijakan (kridawati, 2011:171-172, yang artinya implementasi kebijakan merupakan tahapan yang bersifat praktis dan dibedakan dari formulasi kebijakan yang dapat dipandang sebagai tahapan yang bersifat teoritis. Bisa juga dikatakan bahwa, implementasi kebijakan merupakan proses kegiatan mengeksekusi konsep ke dalam aturan teknis operasional dan program-program kegiatan yang dilakukan setelah kebijakan ditetapkan/disetujui. Kegiatan ini terletak di antara perumusan kebijakan dan evaluasi kebijakan.

Berbicara masalah pelaksanaan suatu kebijakan itu tidak terlepas dari implementasinya yang mana dua-duanya itu tidak bisa terpisahkan. Karena implementasi merupakan langkah yang sangat penting dalam proses kebijakan. Tanpa implementasi, suatu kebijakan merupakan sebuah dokumen yang tidak bermakna dalam kehidupan masyarakat. (Abidin.2016:145).

Berdasarkan Undang-Undang No. 25 Tahun 2004, Sistem Perencanaan Pembangunan Nasional (SPPN) adalah suatu kesatuan tata cara perencanaan pembangunan untuk menghasilkan/mengimplementasikan rencana-rencana Pembangunan jangka panjang, jangka menegah dan tahunan, yang dilaksanakan oleh unsur peyelenggara negara dan masyarakat di tingkat Pusat dan Daerah.

\section{Metode Penelitian}

Penelitian ini dengan jenis deskriptif kualitatif sebagaimana dijelaskan oleh Moleong (2017) dengan melalui sumber data primer dan data skunder yang dijelaskan oleh Moleong (2017) sementara dalam teknik penentuan informan menggunakan 
purposive sampling, sedangkan dalam teknik pengumpulan data melalui wawancara, pengamatan, dan dokumentasi Moleong (2017) dan teknik analisis menggunakan reduksi data, penyajian data, dan penarikan kesimpulan Sugiyono (2018) dengan keabsahan data menggunakan trianggulasi Sugiyono (2018)

\section{Implementasi Kebijakan Musyawarah}

Perencanaan

Pemabngunan

(Musrenbang) di Kabupaten Sumenep

Implementasi kebijakan adalah suatu penentu atas keberhasilan dari hasil Musyawarah Perencanaan Pembangunan (Musrenbang) di Kabupaten Sumenep. Disisi lain pelaksanaan Musyawarah Perencanaan Pembangunan (Musrenbang) bukan hanya sekedar memenuhi kewajiban untuk melaksankan program wajib yang di intruksikan dari Pusat, melainkan memenuhi kewajiban untuk mengimplementasikan atas usulanusalan program prioritas pada proses hasil Musayawarah Perencanaan Pembangunan (Musrenbang) di kabupaen Sumenep.

\section{Hasil Usulan Program Musrenbang} Kabupaten Sumenep
Musyawarah

Perencanaan

Pembangunan (Musrenbang) di Kabupaten Sumenep bisa dikategorikan sudah baik. Dan sudah sesuai dengan teori yang dipakai dalam penelitian ini. Karena yang pertama hasil proses pelaksanaan Musrenbang Kabupaten Sumenep sudah sesuai dengan Visi-Misi Kabupaten Sumenep yang difokuskan pada sektor Pembangunan Kabupaten Sumenep.

Kedua setiap proses pelaksanaan Musrenbang di Kabupaten Sumenep setiap tahunnya semakin meningkat, salah satu contohnya mempamirkan produk-produk unggulan. disisi lain dalam ukuran keberhasilan proses pelaksanaan Musrenbang Kabupaten Sumenep sudah mencerminkan dengan baik, kareana setiap hasil program yang diusulkan diterima dan benar-benar diimplementasikan dengan baik termasuk dari beberapa usulan terkait pembenahan infrastruktur dan pemekaran Desa. Dan hal ini terbukti bahwa dalam proses Musrenbang di Kabupaten Sumenep sudah menerapkan Musyawarah dengan baik seperti dalam teorinya Miftahul Huda dalam bukunya.

Selain keberhasilan proses pelaksanaan Musyawarah Perencanaan Pembangunan (Musrenbang) di 
Kabupaten Sumenep program-program yang diusulkan sudah benar-benar diimplementasikan, walaupun ada beberapa program yang tidak trealisasi. Tetapi hal ini bisa dimaklumi karena keterbatasan anggaran yang ada di Kabupaten Sumenep. Tapi setidaknya dalam pengimplementasian hasil Musrenbang di kabupaten Sumenep itu sudah sama dengan pendapat kridawati dalam bukunya, bahwa implementasi merupakan suatu aktivitas yang bertalian dengan penyelesaian suatu pekerjaan dengan penggunaan sarana (alat) untuk memperoleh hasil.

\section{Implementasi Hasil Musrenbang}

\section{Kabupaten Sumenep}

Badan perncanaan Pembangunan

Daerah BAPPEDA sudah memberikan catatan hasil program prioritas pada proses pelaksanaan Musrenbang pada instansi yang bersangkutan. Dan laporan yang didapat dari instansi kepada BAPPEDA bahwa hasil program yang diusulkan hampir sudah trealisasi, cuma ada beberapa sebagian program yang tidak trealisasi. Tetapi hal ini bisa dimaklumi bahwa tidak trealisasinya program yang diusulkan karena faktor keterbatasan anggaran yang dikelola. Termasuk stetmen dari salah satu anggota DPR-D Kabupaten Sumenep bahwa pertanggungjawaban pelaksanaan Anggaran Pendapatan dan Belanja Daerah (APBD) sudah sesuai dengan RKPD dan diimplementasikan dengan baik. Walaupun ada beberapa program yang belum trealisasi, hal ini disebabkan keterbatasan anggaran di Kabupaten Sumenep.

Jadi dalam pengimplementasisan hasil Musrenbang itu tidak selamanya berjalan sesuai yang diharapkan, seperti pendapat Djadja Saefullah dalam bukunya bahwa implementasi kebijakan sebagai salah satu aktivitas dalam proses kebijakan publik, sering bertentangan dengan yang diharapkan, bahkan menjadikan produk kebijakan itu sebagai menjadi batu sandungan bagi pembuat kebijakan itu sendiri. Tapi setidaknya dalam Implementasi hasil Musrenbang Kabupaten Sumenep yang pertama program yang diusulkan dari tingkat Desa yang sudah diterima pada proses pelaksanaan Musrenbang Kabupaten sudah trealisasi, yang kedua hasil program yang diusulkan dalam proses pelaksanaan Musrenbang Kabupaten Sumenep sudah bisa dirasakan oleh masyarakat sekitarnya. Salah satu program yang dirasakan adalah proyek perbaikan jalan yang sudah rusak. 
Model Strategi Untuk Mecapai

Kesuksesan Implementasi Kebijakan Musrenbang tingkat Kabupaten/Kota Suemenep

Model strategi untuk mencapai kesuksesan kebijakan Musrenbang di tingkat Kabupaten Sumenep tidak tentu dalam menerapkannya dalam artian kondisional. Yang mana dalam mengimplementasikan hasil Musrenbang mempunyai gaya atau strategi yang berbeda. Strategi yang di pakai oleh KESBANGPOL adalah menganalisis kegagalannya dari proses implementasi sebelumnya.

Strategi yang di terapkan oleh pegawai kecamatan melihat pada kebutuhan masyarakat yang bekerja sama dengan ORMAS dan pihak pemerintah kecamatan dalam mensukseskan tujuan yang akan dicapai. Disisi lain juga perumusan strategi yang diterapkan oleh pemerintah Desa lebih pada penguatan Organisasi yang ada di desanya. Karena pemantauan dan kerjasama dari berbagai organisasi yang ada disetiap Desa. Tetapi bukan berarti hanya sebatas memantau proses kebijakan di desanya, melainkan ikut berperanserta dalam prumusan strategi tersebut.
Dari semua strategi yang diterapkan dari berbagai instansi tidak sama antara satu dengan yang linnya dalam dalam mengimplementasikan kebijakan hasil Musyawarah Perencanaan Pembangunan

(Musrenbang) di Kabupaten Sumenep. Hal ini memang sesuai dengan teori dalam prumusan strategi, yang mana mnurut kridawati bahwa ada beberapa model implementasi kebijakan yang bisa terjadi sama atau berbeda antara satu dengan yang lainnya karena di pengaruhi oleh ruang dan waktu. Jadi keberhasilan suatu rencana Pembangunan di Kabupaten Suemenep itu ditentukan oleh instansi itu sendiri dan sadar dengan model strategi yang di bangun oleh penyelenggara kebijakan Musrenbang Kabupaten Sumenep tentunya, karena dalam strategi itulah ada beberapa model untuk menuju kesuksesan sebuah proses implemnetasi kebijakan hasil Musrenbang di Kabupaten Sumenep.

\section{Kesimpulan}

1. Dari hasil Musyawarah Perencanaan Pembangunan (Musrenbang) Kabupaten Sumenep sudah di Implementasikan dengan baik. Baik dari mulai prosesnya sampai implementasi kebijakan 
Musrenbang tersebut. Walaupun ada beberapa sebagian program yang tidak trealisasi. Akan tetapi hal tersebut bisa dimaklumi bahwa tidak trealisasinya program yang diusulkan karena faktor keterbatasan anggaran Daerah Kabupaten Sumenep, dan hal itu tentunya tidak lepas dari Anggaran Pendapatan Belanja Daerah (APBD) yang sesuai dengan Rencana Kerja Pemerintah Daerah (RKPD) Kabupaten Sumenep.

2. Sedangkan model strategi implementasi kebijakan Musrenbang yang diterapkan dari berbagai instansi mulai tingkat Desa sampai tingkat Kabupaten melaksanakan strategi sebagai berikut :
a. KESBANGPOL adalah menganalisis kegagalannya dari proses implementasi sebelumnya

b. KECAMATAN melihat pada kebutuhan masyarakat yang bekerja sama dengan ORMAS

c. DESA lebih pada penguatan Organisasi yang ada di desanya.

Jadi strategi yang diterapkan oleh berbagai instansi menunjukkan gaya model incremental dalam mengimplementasikan hasil Musrenbang Kabupaten Sumenep.

\section{Daftar Pustaka}

Arikunto, Suharsimi. 2017. Pengembangan Instrumen Penelitian dan Penilaian program. . Yogyakarta : Pustaka Pelajar

Akadun, 2011. Revitalisasi Forum Musrenbang sebagai Wahana Partisipasi Masyarakat dalam Perencanaan Pembangunan Daerah. Mimbar.

Badan Pusat Statistik Kabupaten Sumenep. 2018. Sumenep Dalam Angka 2018. BPS Kabupaten Sumenep

Handoko, T. Hani. 2015. Manajemen. Edisi 2. Yogyakarta: BPFE

Mulyadi, Deddy, 2015, Study Kebijakan Publik dan Pelayanan Publik, Bandung: Alfabeta.

Moleong. 2017. Metodologi Penelitian Kualitatif. Bandung: PT Remaja Rosdakarya.

Rulam Ahmadi. 2016. Metodologi Penelitian Kualitatif. Yogyakarta : Ar-Ruzz Media. 
Said Zainal Abidin, 2016. Kebijakan Publik. Jakarta: Penerbit Salemba Humanika.

Suharsimi Arikunto. 2000. Manajemen Penelitian. Jakarta: Rineka Cipta.

Sugiono. 2018. Metode Penelitian Kuantitatif-Kualitatif dan $R \& D$

Suherman. Nandang (P3ML) \&Muluk. Saeful. 2008. Panduan Penyelenggaraan Musyawarah Perencanaan Pembangunan Kabupaten/Kota. Bandung: FPPM

Surat Bersama Mentri Negara Perencanaan Pembangunan Nasional/kepala BAPPENAS dan Mentri Dalam Negeri tentang Pedoman Pelaksanaan Forum Musrenbanng dan Perencanaan Partisipatif Daerah Nomeor : 1354/M.PPN/13/2014.

Tahir, Arifin, 2016. Kebijakan Publikdan Transparansi Penyelenggaraan Pemerintahan Daerah, Penerbit PT. Pustaka Indonesia Press Jakarta.

Uno, Hamzah B, 2016. Perencanaan Pembelajaran. Jakarta: PT Bumi Aksara. Bandung: ALFABETA.
Undang-Undang No. 25 Tahun 2004, Sistem Perencanaan Pembangunan Nasional (SPPN)

Zulkarimen Nasution, 2007. Komunikasi Pembangunan (Pengenalan Teoridan Penerapannya). Jakarta PT Raja Grafindo Persada.

Zulkarnaen, Iskandar, 2003. Sejarah Sumenep, Dinas Pariwisata dan Kebudayaan Kabupaten Sumenep 